\title{
Phenotypic identification of soil bacterial and fungal communities inhabiting an archaeological monument at Augustine University, Ilara Epe, southwest Nigeria
}

\author{
*Ajayi, A. A., Onipede, G. O., Okafor, B. C., Adepoju, K. A., and Nwabuenu, J. C. \\ Department of Biological Sciences, Augustine University, Ilara Epe, Lagos State, Nigeria \\ *Correspondence to: adesola.ajayi@augustineuniversity.edu.ng
}

\begin{abstract}
:
Background: The Sungbo Eredo Monument is an ancient public work with a system of defensive walls and ditches located in Eredo Local Council Development Area of Epe, Lagos State, southwest Nigeria. A huge section of the monument cuts through the Augustine University campus, forming two-sided vertical walls with a deep ridge inbetween. The objective of this investigative study is to determine the microbial profile of soil samples from the monument in the University campus.

Methodology: Soil samples were collected from the topsoil at a depth of $7.5 \mathrm{~cm}$ from four randomly selected points along the edge of the monument. The samples were transported to the microbiology laboratory of the Department of Biological Sciences of Augustine University for analysis. Samples were cultured on Nutrient agar (NA) and incubated aerobically for 24-48 hours for bacteria isolation and on Sabouraud's Dextrose agar (SDA) for 72 hours for fungi isolation. Bacterial colonies on NA were preliminarily identified to genus level by Gram reaction and conventional biochemical test scheme for Gram-positive (catalase, coagulase, starch hydrolysis) and Gram-negative isolates (oxidase, urease test, indole, methyl red, Voges Proskauer and sugar fermentation tests). Fungi colonies on SDA were identified using conventional macroscopic and microscopic characteristics. Antibiotic susceptibility test of the bacterial isolates to selected antibiotics was done using the Kirby Bauer disc diffusion method.

Results: A total of twenty-three bacterial isolates in four genera; Bacillus, Staphylococcus, Cellobiococcus and Micrococcus and nine fungal isolates in three genera; Saccharomyces, Aspergillus and Botrytis were identified from the cultures. The bacterial isolates were sensitive (>50\% sensitivity) to only gentamicin and ofloxacin, with $65.2 \%$ and $78.3 \%$ sensitivity rates respectively, while they were largely resistant to all other antibiotics such as ceftriaxone, erythromycin, cefuroxime, cloxacillin, ceftazidime and augmentin, with resistance rates of $65.2 \%$, $65.2 \%, 73.9 \%, 82.6 \%, 86.9 \%, 91.3 \%$ respectively.

Conclusion: The results of this investigative study revealed the presence of antibiotic-resistant bacteria (mainly Gram-positive) and fungi on the archaeological monument of Augustine University, adding to the existing data on microbial spectrum of archaeological monuments that could be useful for unraveling human cultural habits and microbe-related human diseases. However, further studies on molecular identification of these microbial spectrum will be required to ascertain their genetic relatedness and ancestral phylogeny, which will be useful for archaeologists in their study of the Sungbo-Eredo ancestral monument.
\end{abstract}

Keywords: Archaeology; microbial profile; soil; antibiotic resistance; southwest Nigeria

Received Mar 15, 2021; Revised Jun 22, 2021; Accepted Jul 10, 2021

Copyright 2021 AJCEM Open Access. This article is licensed and distributed under the terms of the Creative Commons Attrition 4.0 International License $<$ a rel="license" href="http://creativecommons.org/licenses/by/4.0/", which permits unrestricted use, distribution and reproduction in any medium, provided credit is given to the original author(s) and the source. Editor-in-Chief: Prof. S. S. Taiwo

\section{Identification phénotypique des communautés bactériennes et fongiques du sol habitant un monument archéologique à I'Université Augustine, Ilara Epe, sud-ouest du Nigeria}

\author{
*Ajayi, A. A., Onipede, G. O., Okafor, B. C., Adepoju, K. A., et Nwabuenu, J. C.
}


Département des sciences biologiques, Université Augustine, Ilara Epe, État de Lagos, Nigéria

*Correspondance à: adesola.ajayi@augustineuniversity.edu.ng

\section{Abstrait:}

Contexte: Le monument Sungbo Eredo est un ancien ouvrage public doté d'un système de murs défensifs et de fossés situé dans la zone de développement du conseil local d'Eredo à Epe, dans l'État de Lagos, au sud-ouest du Nigéria. Une énorme section du monument traverse le campus de l'Université Augustine, formant des murs verticaux à deux côtés avec une crête profonde entre les deux. L'objectif de cette étude d'investigation est de déterminer le profil microbien d'échantillons de sol provenant du monument du campus universitaire.

Méthodologie: Des échantillons de sol ont été prélevés dans la couche arable à une profondeur de 7,5 cm à partir de quatre points choisis au hasard le long du bord du monument. Les échantillons ont été transportés au laboratoire de microbiologie du Département des sciences biologiques de l'Université Augustine pour analyse. Les échantillons ont été cultivés sur gélose nutritive (NA) et incubés en aérobie pendant 24 à 48 heures pour l'isolement des bactéries et sur gélose au dextrose de Sabouraud's (SDA) pendant 72 heures pour l'isolement des champignons. Les colonies bactériennes sur NA ont été préalablement identifiées au niveau du genre par réaction de Gram et schéma de test biochimique conventionnel pour les isolats Gram-positif (catalase, coagulase, hydrolyse de l'amidon) et Gram-négatif (oxydase, test à l'uréase, indole, rouge de méthyle, Voges Proskauer et sucre essais de fermentation). Les colonies de champignons sur SDA ont été identifiées en utilisant des caractéristiques macroscopiques et microscopiques conventionnelles. Le test de sensibilité aux antibiotiques des isolats bactériens à des antibiotiques sélectionnés a été effectué en utilisant la méthode de diffusion sur disque de Kirby Bauer. Résultats: Un total de vingt-trois isolats bactériens dans quatre genres; Bacillus, Staphylococcus, Cellobiococcus et Micrococcus et neuf isolats fongiques de trois genres; Saccharomyces, Aspergillus et Botrytis ont été identifiés à partir des cultures. Les isolats bactériens étaient sensibles (sensibilité $>50 \%$ ) uniquement à la gentamicine et à l'ofloxacine, avec des taux de sensibilité de $65,2 \%$ et $78,3 \%$ respectivement, alors qu'ils étaient largement résistants à tous les autres antibiotiques comme la ceftriaxone, l'érythromycine, la céfuroxime, la cloxacilline, la ceftazidime et l'augmentine avec des taux de résistance de 65,2\%, 65,2\%, 73,9\%, 82,6\%, 86,9\%, 91,3\% respectivement.

Conclusion: Les résultats de cette étude d'investigation ont révélé la présence de bactéries résistantes aux antibiotiques (principalement à Gram positif) et de champignons sur le monument archéologique de l'Université Augustine, ajoutant aux données existantes sur le spectre microbien des monuments archéologiques qui pourraient être utiles pour démêler l'homme. les habitudes culturelles et les maladies humaines liées aux microbes. Cependant, d'autres études sur l'identification moléculaire de ces spectres microbiens seront nécessaires pour déterminer leur parenté génétique et leur phylogénie ancestrale, ce qui sera utile aux archéologues dans leur étude du monument ancestral Sungbo-Eredo.

Mots-clés: Archéologie; profil microbien; sol; résistance aux antibiotiques; sud-ouest du Nigéria

\section{Introduction:}

The soil harbors many forms of microorganisms, majorly bacteria and fungi (1). The soil microbial community shows multiple levels of biological organization which encourages genetic variability as well as evenness among communities (2). The Sungbo Eredo Monument is a system of defensive walls and ditches built in honour of the Ijebu noblewoman, Oloye Bilikisu Sungbo in 800-1000 AD. The Sungbo Eredo is the outer enclosure of Ijebuland in southwestern Nigeria, approximately $180 \mathrm{~km}$ in length, forming a large feature that shows how involved the socio-political system was long before the opening of the Atlantic trade (3). It is a system of ditch and bank that surrounds the whole of Ijebu kingdom (4), and indeed the most significant earthwork of the ancient ramparts, boundary embankments and ditches that stretched across Nigeria (5).

Analyses of samples at various archaeological sites have witnessed new direction of analysis that has led to drastic changes in the formulation of theories. There are adequate records of such observations obtained from the analysis of samples from excavations and other archaeological sites from different parts of the world $(4,6)$. Garg and Shukla (7) reported that efforts should be concentrated on performing microbiological analysis of rare archaeological samples and rationalizing the need for such integration towards better scientific and comprehensive approach. It has been reported that on the time scales of human history and archaeology, microbiological data can contribute to unraveling human cultural habits, microbe-related human diseases and alterations in cultural artifacts due to biochemical reactions (8).

Studies of microbial biogeography have focused on the microbial communities across spatial distance, and other than revealing a causal relationship between microbes and their environments, provides insights into possible environmental drivers of change in microbial communities (9). The objective of this investigative study is to determine the microbial profile of soil samples from the monument in the University campus. 


\section{Materials and method:}

\section{Sample collection}

Soil samples were collected from four randomly selected points $(A, B, C, D)$ along the edge of the monument. They were obtained from topsoil at a depth of $7.5 \mathrm{~cm}$ with a sterile spatula into sterile Bijou bottles according to the method described by Ogunmwonyi et al., (10). The bottles were placed in a beaker and transported back to the microbiology research laboratory of the Department of Biological Sciences, Augustine University, Ilara Epe, Lagos State, Nigeria for microbial analysis.

\section{Determination of pH of soil sample}

The $\mathrm{pH}$ of the soil samples was determined according to the method described by Ogunmwonyi et al., (10) using a pH meter (Jenway Model 3505, UK). The soil samples were mixed with distilled water in the ratio of 1:2 after which it was stirred for 30 minutes, and allowed to settle before the $\mathrm{pH}$ meter probe was inserted into the mixture.

\section{Inoculation of cultures}

A 10 -fold serial dilution of the soil samples was done and the diluted samples were plated on Nutrient agar (Biolab, UK) for bacteria and Saboraoud Dextrose agar (SDA) for fungi using the pour plate method. NA plates were incubated at $37^{\circ} \mathrm{C}$ aerobically for 24-48 hours while SDA plates were incubated at $25^{\circ} \mathrm{C}$ and $37^{\circ} \mathrm{C}$ for 72 hours.

\section{Bacterial identification}

Colonies of bacteria on the NA plates were identified to genus level using cultural morphology (surface appearance, size, shape, pigmentation) (11), Gram staining reaction, and conventional biochemical test scheme for Gram positive (catalase, coagulase, starch hydrolysis) and Gram-negative bacteria (urease, methyl red, Voges Proskauer, and sugar fermentation tests) as previously described by Ajayi et al., (12).

\section{Fungal identification}

The identification of the fungal isolates was based on a combination of morphological and cultural characteristics with special reference to the sporulation of the fungal isolates. Macroscopic examination was done by direct observation of the SDA plates and wet mount microscopy of fungal cultures. Physical appearance such as the colony colour, shape and texture (moist mycelia) were examined first as well as abundance of growth. This was carried out using the techniques contained in the illustrated handbook of fungi $(13,14)$. A wet mount of each fungus was prepared by suspending a loopful of the fungal culture in a few drops of lacto-phenol cotton blue solution on a microscope slide, which was then covered with a slip and examined under the light microscope with 40x magnification lens.

Antibiotic susceptibility test of bacterial isolates Antibiotic susceptibility of each isolated bacteria was determined using the Kirby-Bauer disk diffusion method to selected antibiotics on Mueller-Hinton (MH) agar plates. Antibiotics disks (Rapid Labs CM-12-8PR100, UK) used were; ceftazidime $(30 \mu \mathrm{g})$, cefuroxime $(30 \mu \mathrm{g})$, gentamicin $(10 \mu \mathrm{g})$, ceftriaxone $(30 \mu \mathrm{g})$, erythromycin $(5 \mu \mathrm{g})$, cloxacillin $(5 \mu \mathrm{g})$, ofloxacin (5 $\mu \mathrm{g})$, and augmentin ( $30 \mu \mathrm{g})$.

Inoculum of each isolate was first prepared in $0.9 \%$ saline and standardized by comparing with 0.5 MacFarland turbidity standard. Sterile $\mathrm{MH}$ agar plate was inoculated with the standardized inoculum using sterile cotton swab, and antibiotic disks were placed on the plate, which was then incubated aerobically at $37^{\circ} \mathrm{C}$ for 24 hours. The diameter of zones of growth inhibition around each disc was measured and the result was interpreted as sensitive, intermediate or resistant using the Clinical and Laboratory Standards Institute (CLSI) guideline (15).

\section{Results:}

The $\mathrm{pH}$ of the soil samples from the four sites in Sungbo Eredo Monument on Augustine University are; pH 5.9 (A), pH 6.3 (B), pH 6.0 (C), and $\mathrm{pH} 6.3$ (D). The bacterial and fungal isolates from soil samples obtained from the monument are shown in Tables 1,2 and 3. A total of twenty-three bacterial isolates in four genera; Bacillus, Staphylococcus, Cellobiococcus and Micrococcus and nine fungal isolates in three genera; Saccharomyces, Aspergillus and Botrytis were isolated from the monument.

The results of the antibiotic susceptibility test showed that the bacterial isolates were sensitive ( $>50 \%$ sensitivity) to only gentamicin and ofloxacin, with $65.2 \%$ and $78.3 \%$ sensitivity rates respectively, while they were largely resistant to all other antibiotics such as ceftriaxone, erythromycin, cefuroxime, cloxacillin, ceftazidime and augmentin, with resistance rates of $65.2 \%, 65.2 \%, 73.9 \%, 82.6 \%, 86.9 \%$, and $91.3 \%$ respectively (Table 4 ). 
Table 1: Colonial and morphological characteristics of bacterial isolates from archaeological monument at Augustine University, Ilara Epe, southwest Nigeria

\begin{tabular}{ccccccc}
\hline S/N & $\begin{array}{c}\text { Isolate } \\
\text { code }\end{array}$ & Colony colour & $\begin{array}{c}\text { Colony } \\
\text { surface }\end{array}$ & $\begin{array}{c}\text { Gram } \\
\text { reaction }\end{array}$ & Cell shape & Cell arrangement \\
\hline 1 & A1 & Creamy & Shiny & + & Cocci & Clustered \\
2 & A2 & Milky & Shiny & + & Rods & Pairs \\
3 & A3 & Milky & Shiny & + & Rods & Chains \\
4 & A4 & Creamy & Shiny & + & Rods & Chains \\
5 & A5 & Milky & Shiny & + & Cocci & Chains \\
6 & A6 & Milky & Shiny & + & Rods & Chains \\
7 & A7 & Milky & Moist & + & Cocci & Chains \\
8 & A8 & Milky & Slimy & + & Rods & Chains \\
9 & A9 & Milky & Viscous & + & Rods & Chains \\
10 & B10 & Milky & Viscous & + & Rods & Pairs \\
11 & B11 & Milky & Viscous & + & Rods & Chains \\
12 & B12 & Milky & Slimy & + & Rods & Slimy \\
13 & B13 & Milky & Slimy & + & Cocci & Pairs \\
14 & B14 & White & Viscous & + & Rods & Clustered \\
15 & B15 & White & Shiny & + & Rods & Chains \\
16 & B16 & Milky & Moist & + & Rods & Chains \\
17 & B17 & Milky & Shiny & + & Rods & Pairs \\
18 & B18 & Creamy & Moist & + & Rods & Clustered \\
19 & C19 & Milky & Viscous & + & Rods & Chains \\
20 & C20 & Milky & Moist & + & Rods & Clustered \\
21 & C21 & Yellow & Shiny & + & Cocci & Chains \\
22 & C22 & Orange & Shiny & + & Rods & Chains \\
23 & C23 & Orange & Moist & + & Rods & Pairs \\
\hline
\end{tabular}

Table 2: Biochemical characteristics of bacterial isolates from archaeological monument at Augustine University, Ilara Epe, southwest Nigeria

\begin{tabular}{|c|c|c|c|c|c|c|c|c|c|c|}
\hline $\mathbf{S} / \mathbf{N}$ & $\begin{array}{c}\text { Isolate } \\
\text { code }\end{array}$ & $\begin{array}{c}\text { Catalase } \\
\text { test }\end{array}$ & Coagulase & $\begin{array}{c}\text { Starch } \\
\text { hydrolysis }\end{array}$ & $\begin{array}{c}\text { Urease } \\
\text { test }\end{array}$ & $\begin{array}{l}\text { Methyl } \\
\text { red test }\end{array}$ & $\begin{array}{c}\text { Vogues- } \\
\text { Proskauer } \\
\text { test }\end{array}$ & $\begin{array}{c}\text { Lactose } \\
\text { fermentation }\end{array}$ & $\begin{array}{c}\text { Sucrose } \\
\text { fermentation }\end{array}$ & $\begin{array}{c}\text { Most probable } \\
\text { bacteria }\end{array}$ \\
\hline 1 & $\mathrm{~A} 1$ & + & - & + & - & - & - & - & - & Micrococcus sp \\
\hline 2 & $A 2$ & + & - & + & - & - & - & $A G$ & AG & Bacillus sp \\
\hline 3 & A3 & + & - & + & - & - & - & - & - & Bacillus sp \\
\hline 4 & A4 & + & - & - & - & - & - & - & $\mathrm{A}$ & Bacillus sp \\
\hline 5 & A5 & + & - & + & - & - & - & $A G$ & - & Cellobiococcus sp \\
\hline 6 & A6 & - & - & + & + & - & - & - & - & Bacillus sp \\
\hline 7 & A7 & + & + & + & + & - & - & $A$ & $A$ & Staphylococcus sp \\
\hline 8 & A8 & - & - & + & - & - & - & A & A & Bacillus sp \\
\hline 9 & A9 & + & - & + & + & - & - & - & $A G$ & Bacillus sp \\
\hline 10 & B10 & + & - & + & + & - & - & - & $A$ & Bacillus sp \\
\hline 11 & $\mathrm{~B} 11$ & - & - & + & + & - & - & - & $A$ & Bacillus sp \\
\hline 12 & $\mathrm{~B} 12$ & + & - & + & + & - & - & $A$ & AG & Bacillus sp \\
\hline 13 & B13 & + & - & + & - & - & - & A & $A$ & Cellobiococcus sp \\
\hline 14 & B14 & - & - & + & - & - & - & $A$ & $A G$ & Bacillus sp \\
\hline 15 & B15 & - & - & + & - & - & - & $A$ & A & Bacillus sp \\
\hline 16 & B16 & - & - & + & + & - & - & - & - & Bacillus sp \\
\hline 17 & B17 & - & - & + & + & - & - & AG & AG & Bacillus sp \\
\hline 18 & B18 & + & - & + & - & - & - & - & - & Bacillus sp \\
\hline 19 & C19 & - & - & + & - & - & - & $A$ & $A$ & Bacillus sp \\
\hline 20 & $\mathrm{C} 20$ & + & - & + & - & - & - & - & A & Bacillus sp \\
\hline 21 & $\mathrm{C} 21$ & + & - & + & - & - & - & - & - & Cellobiococcus sp \\
\hline 22 & $\mathrm{C} 22$ & + & - & + & + & - & - & - & $A$ & Bacillus sp \\
\hline 23 & $\mathrm{C} 23$ & + & - & + & + & - & - & - & - & Bacillus sp \\
\hline
\end{tabular}


Table 3: Morphological and microscopic characteristics of fungal isolates from archaeological monument at Augustine University, Ilara Epe, southwest Nigeria

\begin{tabular}{|c|c|c|c|c|}
\hline $\mathbf{S / N}$ & $\begin{array}{l}\text { Isolate } \\
\text { code }\end{array}$ & Morphological Characteristics & Microscopic Characteristics & Isolate Identity \\
\hline 1 & AF1 & Dark Green Spores & $\begin{array}{c}\text { Possession of colourless hyphae, septate and } \\
\text { branched }\end{array}$ & Aspergillus sp \\
\hline 2 & AF2 & Green Spores with white edges & $\begin{array}{c}\text { Possession of colourless hyphae, septate and } \\
\text { branched }\end{array}$ & Aspergillus sp \\
\hline 3 & AF3 & White Spores, & Coenocytic, unicellular, non-septate & Botrytis sp \\
\hline 4 & CF1 & $\begin{array}{c}\text { Yellow Growth, Growth on vitamin free } \\
\text { medium and YEPG Plates ( } 1 \% \text { yeast } \\
\text { extract, } 2 \% \text { glucose, } 1 \% \text { peptone, } \\
1.5 \% \text { agar })\end{array}$ & Unicellular fungus & Saccharomyces sp \\
\hline 5 & CF2 & $\begin{array}{c}\text { Yellow Growth, growth on vitamin free } \\
\text { medium and YEPG Plates ( } 1 \% \text { yeast } \\
\text { extract, } 2 \% \text { glucose, } 1 \% \text { peptone, } \\
1.5 \% \text { agar) }\end{array}$ & Unicellular fungus & Saccharomyces sp \\
\hline 6 & CF3 & Dark Green Spores & $\begin{array}{c}\text { Possession of colourless hyphae, septate and } \\
\text { branched }\end{array}$ & Aspergillus sp \\
\hline 7 & CF4 & Dark-Green Spores & $\begin{array}{c}\text { Possession of colourless hyphae, septate and } \\
\text { branched }\end{array}$ & Aspergillus sp \\
\hline 8 & CF5 & $\begin{array}{l}\text { White filamentous fungi. Tips turned } \\
\text { yellow over time }\end{array}$ & $\begin{array}{l}\text { Septate, filamentous, possession of loose } \\
\text { grey material on mycelium surface }\end{array}$ & Botrytis sp \\
\hline 9 & DF1 & White Spores & $\begin{array}{l}\text { Septate, filamentous, possession of loose } \\
\text { grey material on mycelium surface }\end{array}$ & Botrytis sp \\
\hline
\end{tabular}

Table 4: Antibiotic susceptibility of isolated bacteria from archaeological monument at Augustine University, Ilara Epe, southwest Nigeria to selected antibiotics

\begin{tabular}{|c|c|c|c|c|}
\hline Antibiotics & $\begin{array}{c}\text { Number of } \\
\text { isolates tested }\end{array}$ & $\begin{array}{c}\text { Number of sensitive } \\
\text { isolates }(\%)\end{array}$ & $\begin{array}{c}\text { Number of intermediate } \\
\text { isolates }(\%)\end{array}$ & $\begin{array}{c}\text { Number of resistant } \\
\text { isolates }(\%)\end{array}$ \\
\hline Ceftriaxone (CTR) & 23 & $7(30.4)$ & $1(4.4)$ & $15(65.2)$ \\
\hline Erythromycin (ERY) & 23 & $6(26.1)$ & $2(8.7)$ & $15(65.2)$ \\
\hline Cloxacillin (CXC) & 23 & $4(17.4)$ & 0 & $19(82.6)$ \\
\hline Ofloxacin (OFL) & 23 & $18(78.3)$ & $4(17.4)$ & $1(4.4)$ \\
\hline Augmentin (AUG) & 23 & $2(8.7)$ & 0 & $21(91.3)$ \\
\hline Ceftazidime (CAZ) & 23 & $3(13.0)$ & 0 & $20(86.9)$ \\
\hline Cefuroxime (CFX) & 23 & $4(17.4)$ & $2(8.7)$ & 17 (73.9) \\
\hline Gentamicin (GEN) & 23 & $15(65.2)$ & $3(13.0)$ & $5(21.7)$ \\
\hline
\end{tabular}

\section{Discussion:}

The results of this investigative study of the microbiological profile of soil samples from Sungbo Eredo Monument on Augustine University, Ilara Epe campus, Lagos, Nigeria revealed a total of twenty-three bacterial isolates belonging to genera Bacillus, Staphylococcus, Cellobiococcus and Micrococcus and nine fungal isolates belonging to the genera Saccharomyces, Aspergillus and Botrytis. Realini et al., (16) also reported a variety of organisms including bacteria and fungi in the degradation of monuments, Bhatnagar et al., (17) reported Bacillus sp., Staphylococcus sp., and Micrococcus sp., as part of the bacteria found in monuments and objects of archaeological importance, and Omar et al., (18) reported that microbial swabs taken from infected artefacts from museum objects and rock monuments had microorganisms of the genera Aspergillus, Penicillium, Acremonium, Rhizopus, Cladosporium, Torula and Alternaria with the genus Aspergillus being the dominant genus (49.6\% of the total fungal isolates) followed by Penicillium and Acremonium.
The soil is known to harbor enormous diversity of microorganisms among which are bacteria and fungi that may play pivotal roles for ecosystem functioning such as regulating organic matter decomposition, soil dynamics, and mediating nutrient cycling (2). A large percentage of the world's stone cultural heritage monuments have suffered severe and irreversible degradation and deterioration from microorganisms. This damage and deterioration not only cause loss of aesthetic values but presents challenges to researchers exploring the evolution of ancient civilizations (19).

There have been reports of archaeological observations and analysis of samples from excavations on the Sungbo Eredo monument. However, our study is the first to report bacterial and fungal isolates from the Sungbo Eredo monument, which agrees with the submission of previous researchers on the use of microbiology as a tool for providing information and valuable data for past events. There are ample records of such observations from analysis of samples from excavations and other archaeological sites from different parts of the world. Garg and Shukla (7) reported that the 
use of microbiology as a tool outside biological fields provides valuable data to complement and upgrade knowledge about past events. For example, on a geological scale, microbiological data can contribute to the understanding and reconstruction of past climatological, environmental, and sedimentary conditions. Moreover, on the time scales of human history and archaeology, microbiological data can contribute to unraveling human cultural habits, microberelated human diseases, and alterations in cultural artefacts due to biochemical reactions (9).

The results of the antimicrobial susceptibility test showed that ofloxacin and gentamicin were the two antibiotics the bacterial isolates in our study were susceptible to, with $78.3 \%$ and $65.2 \%$ sensitivity rates respectively, while they were largely resistant to the other antibiotics. This finding is similar to the study of Owolabi and Hekeu (20) who reported high resistance of three bacteria isolates recovered from polluted soils in Lagos and Ota, Nigeria to amoxicillin, augmentin, cefuroxime, erythromycin and cloxacillin, with sensitivity to only ofloxacin and ceftazidime. This implies that soil samples from the monument and polluted soils may serve as reservoir of antimicrobial resistant (AMR) organisms, that have the potential of being transmitted to humans and animals through contamination of water sources or animal feeds.

The $\mathrm{pH}$ of the soil samples collected from different spots on the monument showed values ranging from 5.9 to 6.3. These values are indicative of an acidic soil. Li et al., (19) reported soil $\mathrm{pH}$ as the key predictor of soil bacterial community composition and diversity. Neina (21) reported that soil $\mathrm{pH}$ is the "master soil variable" that influences myriads of soil biological, chemical, and physical properties and processes that affect plant growth and biomass yield. At very acidic or alkaline levels, organic matter mineralization is reduced severely or stopped due to poor microbial activity. Acidic soil had been identified to support the growth of bacteria poorly while favouring the growth of fungi. Beneficial soil microbes prefer a near neutral $\mathrm{pH}$ range of $6-7$ (10). Cho et al., (22) however reported that results and indices regarding diversity, richness, and evenness examined in their study indicated that $\mathrm{pH}$ alone might not play the main role for bacterial diversity in soil.

\section{Conclusion:}

The results of our investigative study revealed the presence of antibiotic-resistant bacteria (mainly Gram-positive) and fungi on the soil samples of Sungbo Eredo archaeological monument, adding to the existing data on microbial spectrum of archaeological monuments that could be useful for unraveling human cultural habits and microbe-related human diseases. Microbial communities inhabiting the monument will definitely have significant influences on the terrestrial ecosystem dynamics. However, further studies on molecular identification of these microbial spectrum will be required to ascertain their genetic relatedness and ancestral phylogeny, which will be useful for archaeologists in their study of the Sungbo-Eredo ancestral monument.

\section{References:}

1. Singh, D. P., and Prabha, R. Microbial Interventions in Agriculture and Environment. Springer, Singapore.2019: 491

2. Zheng, Q., Hu, Y., Zhang, S., et al. Soil multifunctionality is affected by the soil environment and by microbial community composition and diversity. Soil Biol. Biochem. 2019;136: 107521

3. Chouin, G. L. Rethinking the Chronology of Sungbo Eredo: Recent Archaeological Investigations in Ijebuland. $59^{\text {th }}$ Annual Conference of African Studies Association, Washington DC, 2016

4. Lasisi, O. B. "History of Archaeological Research in the Yoruba-Edo Region of Nigeria: New Directions for Urban Earthen works" Dissertations, Thesis and Masters Projects. 2018; 1550153837

5. Aremu, D. A. Saving Sungbo Eredo: A Challenge to Nigerian Archaeologists. West Afr J Archaeol. 2002; 32 (2): 63-73

6. Connah, G. African city walls a neglected source? In: Anderson, D., and Rathbone, R (eds.), Africa's Urban Past, James Currey, Oxford. 2000: 36-51

7. Garg, P., and Shukla, P. Archaeology vis-à-vis Microbiology: Discovering the Vistas of Interdisciplinary Research. Frontier Discoveries and Innovations in Interdisciplinary Microbiology. SpringerLink. 2017; $213-219$

8. Margesin, R., Siles, J. A., Cajthaml, T., Öhlinger, B., and Kistler, E. Microbiology Meets Archaeology: Soil Microbial Communities Reveal Different Human Activities at Archaic Monte Iato (Sixth Century BC).Microb Ecol. 2017; 73 (4): 925-938

9. Lin, Y. T., Lin, Y. F., Tsai, I. J., et al. Structure and Diversity of Soil Bacterial Communities in Offshore Islands. Scientific Reports. 2019; 9: 4689

10. Ogunmwonyi, I. N., Igbinosa, E. O., Aiyegoro, O. A., and Odjadjare, E. E. Microbial analysis of different top soil samples of selected sites in Obafemi Awolowo University, Nigeria. Scientific Research and Essays. 2008; 3 (3): 120 - 124

11. Olutiola, P. O., Famurewa, O., and Sonntag, H. G. An introduction to General Microbiology. A Practical Approach. Heidelberger Verlgsansatalt and Druckerei $\mathrm{GmbH}$, Heidelberg, Federal Republic of Germany. 1991:1 - 267

12. Ajayi, A. A., Osilalu, E. O., Adejuwon, A. O., and Peter-Albert, C. F. Studies on Pectinolytic and Proteolytic Enzymes from Deteriorated Grapes (Vitis vinifera). Covenant Journal of Life and Physical Sciences. 2014; 1(2): 1 - 15

13. Hanlin, R. T. Illustrated Genera of Ascomycetes. Vol.1. Amer Phytopathological Society (ASP) Press, 1990. 
14. Cannon, P. F., and Kirk, P. M. Fungal Families of the World. Wallingford, Oxfordshire, UK, 2007.

15. Clinical and Laboratory Standards Institute (CLSI). Performance standards for antimicrobial susceptibility testing. 28th ed. Supplemental M100. Clinical and Laboratory Standards Institute, Wayne, PA, 2018.

16. Realini, M., Sorlini, C., and Bassi, M. The Certosa of Pavia: a case of Biodeterioration. In Vth International Congress on Deterioration and Conservation of Stone. Proceedings, Vol. 2, ed. G. Felix. Presses Polytechniques Romandes, Lausanne. 185: 627-632

17. Bhatnagar, P., Arif Khan, A., Jain, S. K., and Rai, M. K. Biodeterioration of Archaeological monuments and Approach for Restoration in Geomicrobiology. CRS Press Taylor and Francis Group Science Publishers. 2010. doi: 10 $1201 / 610193-10$
18. Omar, A. M., Taha, A. S., and Mohammed, A. A. A. Microbial Deterioration of some Archaeological Artifacts: Manipulation and Treatment. Euro J Exp Biol. 2018; 8 (4):21

19. Li, Q., Zhang, B., He, Z., and Yang, X. Distribution and Diversity of Bacteria and fungi colonization in stone monuments analyzed by high throughput sequencing. PLoS One. 2016; 11 (9): 0163287

20. Owolabi, J. B., and Hekeu, M. M. Heavy Metal Resistance and Antibiotic Susceptibility Pattern of Bacteria Isolated from Selected Polluted Soils in Lagos and Ota, Nigeria. Int J Basic Appl Sci. 2014; 14 (06): 6142206-7373

21. Neina, D. The Role of Soil pH in Plant Nutrition and Soil Remediation. Appl Environ Soil Sci. 2019: 5794869

22. Cho, S. J., Kim, M. H., and Lee, Y. O. Effect of pH on Soil Bacterial Diversity. J Ecol Environ. 2016; 40: 10 